\title{
Medich giant platelet syndrome
}

INSERM

\section{Source}

INSERM. (1999). Orphanet: an online rare disease and orphan drug data base. Medich giant platelet syndrome. ORPHA:370127

Medich giant platelet syndrome (MGPS) is a platelet granule disorder characterized by thrombocytopenia with giant platelets resulting in easy bleeding. 